\title{
Mengatasi Kerusakan Formasi Dengan Metoda Pengasaman Yang Kompetibel Pada Sumur Minyak Dilapangan X
}

\author{
To Overcome Formation Damage with using Acid wich Compatible \\ to Oil Well In X Field
}

\author{
Ali Musnal \\ Jurusan Teknik Perminyakan Fakultas teknik Universitas Islam Riau Pekanbaru \\ Jl. Kaharuddin Nasution 113 Pekanbaru 28284 \\ ulpti@yahoo.co.id
}

\begin{abstract}
Abstrak
Laju produksi suatu sumur minyak akan mengalami penurunan di akibatkan antara lain menurunnya tekanan reservoir (Pr), dan juga karena terjadi kerusakan formasi produktif.

Adapun type-type penyebab kerusakan formasi itu adalah :

- Scale : Suatu endapan yang terbentuk akibat kristalisasi dari ion-ion mineral yang larut dalam air dan disebabkan oleh adanya senyawa pembentuk kerak didalam air yang melebihi kelarutannya pada keadaan kesetimbangan.

- Clay

: Disebabklan karena fress water atau filtrat Lumpur pemboran yang merembes keformasi yang mengandung shale.

- Partikel Plugging : Partikel lumpur pemboran atau bubur semen dapat menyebabkan tertutupnya pori pori batuan.
\end{abstract}

Untuk melarutkan atau menghilangkan penyebab kerusakan formasi tersebut diatas, dilakukan pengasaman. Sebelum dilakukan pengasaman harus melakukan analisa pemilihan jenis asam yang compatible dengan teknik dan pelaksanaan yang baik dilapangan. Ada 3 jenis pengasaman yang lazim digunakan yaitu : Matrik acidizing, Acid Washing dan Acid Fracturing.Methoda yang dilakukan dalam penelitian ini dengan mengambil data dilapangan seperti, Data Produksi, Water Analysis, Mineralogi, Menghitung Volume Asam,kemudian menghitung parameter skin,laju produksi, produktivitas Indek dan Flow Effisiensi baik sesudah maupun sebelum pengasaman dilakukan. Dari data lapangan ini didapat mineral quartz (grain) sebanyak 71,2\%, illite dan dolomite 4,6\%, calcite $2,3 \%$, kaolinite 1,8 \%, smeltite 0,1 \% dan kandungan kalsium carbonat 22,2 \%,maka dipilih jenis asam yang compatible digunakan yaitu Mud Acid $(\mathrm{HCL}+\mathrm{HF})$, untuk lebih jelas dapat dilihat uraian yang dipaparkan dalam penelitian ini.

Kata Kunci : Kerusakan Formasi,Asam dan Laju Produksi.
Abstract
An oil production rate will decline in causes such as declining reservoir pressure (Pr), and also because there is damage to productive formations. The types are the cause of formation damage that is:
- Scale
: A precipitate formed by crystallization of mineral ions dissolved in water and is caused by the crust-forming compounds in water that exceeds its solubility in the equilibrium state.
- Clay
: Because fress water or drilling Mud filtrate seeping keformasi containing shale. 
- Plugging Particles : Particles drilling mud or cement slurry can lead to the closing of the poresof rocks.

To dissolve or eliminate the causes of formation damage mentioned above, carried acidification. Prior to acidification should analyze the selection of the type of acid that is compatible with good technique and execution in the field. There are 3 types of acidification are commonly used are: Matrix acidizing, Acid Washing and Acid Fracturing.Methoda performed in this study by taking field data such as, Data Production, Water Analysis, Mineralogy, Volume Counting acid, then calculate the parameters of the skin, the rate of production, productivity and Flow Efficiency Index both before and after acidification done. The field data obtained from the mineral quartz (grain) as much as $71.2 \%, 4.6 \%$ illite and dolomite, calcite $2,3 \%, 1.8 \%$ kaolinite, smeltite $0.1 \%$ and $22.2 \%$ calcium carbonate, then selected type of acid used is compatible Mud Acid $(H C L+H F)$, to more clearly seen descriptions presented in this research.

Keywords: Formation Damage, Acid, rate production

\section{PENDAHULUAN}

\subsection{Latar Belakang}

Produksi suatu sumur akan mengalami penurunan produksi.,turunnya laju produksi disebabkan karena adanya kerusakan formasi produktif dan penurunan tekanan reservoir. Kerusakan formasi tersebut dapat ditanggulangi untuk menaikan laju produksi dengan cara melakukan pengasaman pada sumur tersebut Dalam hal ini dipilih jenis asam yang compatible yang akan digunakan dalam peningkatan laju produksi.

Tujuan utama dari pengasaman ini adalah untuk memperbaiki produktifitas suatu sumur. Asam yang dapat digunakan harus bisa melarutkan partikel-partikel formasi dan material-material asing yang dapat masuk kedalam formasi selama proses pengeboran, komplesi sumur dan proses produksi.
Kerusakan suatu formasi menunjukkan daerah disekitar lubang sumur yang mengalami penurunan permeabelitas. Penyebarab kerusakan formasi biasanya hanya beberapa inchi dari lubang sumur, tetapi kadang-kadang dapat pula menyebar jauh sampai beberapa feet. Jangkauan ini merupakan salah satu faktor yang penting dalam pemilihan jenis asam dan teknik pengasamanya.

Adapun tipe-tipe penyebab kerusakan formasi yaitu:

$\Rightarrow$ Scale, Endapan yang terbentuk akibat kristalisasi dari ion-ion mineral yang larut dalam air. Deposit scale disebabkan oleh adanya senyawasenyawa pembentuk kerak didalam air yang melebihi kelarutannya pada keadaan kesetimbangan, selanjutnya akan terjadi pengendapan dimana jumlah molekul akan bertambah dan membentuk kristal yang menempel 
dipermukaan dan selama selang waktu tertentu akan menjadi padatan yang keras.

$\Rightarrow$ Clay Swelling. Disebabkan karena fresh water atau filtrat lumpur pemboran yang merembes keformasi yang mengandung shale. Sekali swelling terjadi sukar sekali untuk menaikkan kembali permeabelitas dengan mengganti sistim lumpur dengan lumpur asin (salt water mud).

$\Rightarrow$ Partikel Plugging. Partikel lumpur pemboran atau semen dapat menyebabkan tertutupnya pori-pori batuan disekitar lubang bor. Selain iti terdapat grup clay illite (seperti rambut) dan kaolinite (berlapis-lapis) yang partikelnya akan bergerak dan menutup lubang pori-pori kalau clay tersebut tersentuh oleh filtrat fresh water base mud, baik silika maupun claynya sendiri.

\subsection{Tujuan Penulisan}

Tujuan meningkatkan produktifitas sumur yang diakibatkan oleh kerusakan formasi dengan cara memilih jenis asam yang cocok dan mengetahui penyebab kecilnya permeabelitas suatu sumur dan kriteria jenis asam.

\subsection{Teori Dasar}

Secara umum pengasaman terbagi atas tiga jenis,yaitu :

a. Acid Washing

Acid washing merupakan suatu operasi yang didisain untuk mengurangi dan menghilangkan scale yang dapat dilarutkan oleh asam, yang terdapat didalam lubang bor atau untuk membuka lubang yang tersumbat oleh scale. Suatu asam yang telah ditentukan volumenya dan juga konsentrasinya berdasarkan perhitungan yang diperlukan, diinjeksikan keinterval-interval tertentu dilubang bor, sehingga akan bereaksi dengan endapan scale. Dengan demikian dapat dihilangkan hambatan aliran pada tubing atau perforasi

b. Matrix cidizing

Pengasaman matrix dilakukan untuk menghilangkan kerusakan formasi (skin demage) yang disebabkan oleh fluida pemboran, komplesi dan kerja ulang sumur (workover) serta menghilangkan endapan (plage) disekitar lubang bor. Asam diinjeksikan dibawah tekanan rekah formai, maka dapat diharapkan perbaikkan atau pertambahan produktifitas sumur. 
c. Acid Fracturing

Asam diinjeksikan keformasi dengan tekanan dan laju injeksi diatas tekanan rekahan formasi. Pengasaman perekahan ini adalah suatu alternatif dari perekahan hidraulik pada reservoir karbonat. Reservoir direkahkan secara hidraulik, kemudian beberapa mineral dipermukaan rekahan dilarutkan oleh asam, sehingga akan memberikan saluran air linier kelubang bor. Konduktifitas rekahan yang tinggi dapat dicapai setelah dilakukan pengasaman ini.

Bentuk reaksi kimia antara asam dengan mineral-mineral batuan sangat penting untuk diketahui, dengan tujuan :

- Sebagai dasar pemilihan jenis asam

- Menentukan jumlah asam yang diperlukan

Berikut ini akan ditunjukkan reaksi-reaksi kimia antara asam $\mathrm{HCl}$ dan $\mathrm{HF}$ dengan mineral-mineral batuan, seperti ditunjukan pada tabel 1 dibawah ini:
Tabel 2 Reaksi Kimia antara $\mathrm{HCl}$ dan $\mathrm{HF}$ dengan Mineral Batuan

\begin{tabular}{|c|c|c|}
\hline Asam & Mineral & Reaksi \\
\hline $\mathrm{HCl}$ & $\begin{array}{l}\text { Calcite } \\
\text { Dolomite } \\
\text { Sidente }\end{array}$ & $\begin{array}{l}2 \mathrm{HCl}+\mathrm{CaCO}_{3} \rightarrow \mathrm{CaCl}_{2}+\mathrm{CO}_{2}+\mathrm{H}_{2} \mathrm{O} \\
4 \mathrm{HCl}+\mathrm{CaMg}_{2}\left(\mathrm{CO}_{3}\right) \longrightarrow \mathrm{CaCl}_{2}+\mathrm{MgCl}_{2}+2 \mathrm{CO}_{2}+ \\
2 \mathrm{H}_{2} \mathrm{O} \\
2 \mathrm{HCl}+\mathrm{FeCO}_{3} \longrightarrow \mathrm{CeCl}_{2}+\mathrm{CO}_{2}+\mathrm{H}_{2} \mathrm{O}\end{array}$ \\
\hline $\mathrm{HF} / \mathrm{HCl}$ & $\begin{array}{l}\text { Quatiz } \\
\text { Albite } \\
\text { Othoclase } \\
\text { Kadinite } \\
\text { Montmonillonite }\end{array}$ &  \\
\hline
\end{tabular}

Pemilihan jenis asam beradasarkan mineralogi dapat dilihat gambar flow chart dibawah ini:

MINERALOGI Special Clay $>=10 \%$



3D-85 
Menghitung volume Konsentrasi asam

Vol Consentrat $e=\frac{\left(\mathrm{Vol}_{\text {laru tan }_{\text {tan }}}\right)\left(\% \mathrm{HCl}_{\text {laru tan }}\right) S G_{\text {laru tan }}}{\left(\% \mathrm{HCl} l_{\text {conseburra to }}\right)\left(S G_{\text {consentrat e }}\right)}$

Pada kondisi sumur yang rusak (formasi demage), penurunan tekanan lebih besar bila dibandingkan dengan kondisi normal, hal ini disebabkan oleh harga pwf semakin turun, sehingga persamaan Darcy untuk aliran steady state menjadi :

Sedangkan untuk menghitung Produktifita Indek dipergunakan peramaan :

$$
\begin{aligned}
q & =\frac{0.00708 \times k \times h \times(p r-p w f)}{\mu_{c} \times B o \times\left(\ln \left(\frac{r e}{r w}\right)+S\right)} \\
P I & =\frac{Q}{\operatorname{Pr}-P w f} \mathbf{I} .
\end{aligned}
$$

Pada Sumur produksi mencari harga skin dengan menggunakan persamaan Darcy, dimana :

$\mathrm{S}=+$, diasumsikan terjadinya kerusakan formasi

$\mathrm{S}=-$, diasumsikan terjadinya perbaikan

$\mathrm{S}=0$, keadaan Normal.

\section{METODA PENELITIAN}

Didalam melakukan penelitian ini meliputi kegiatan kegiatan yang terstruktur mulai dari pencarian masalah, studi literatur dengan mengumpulkan beberapa referensi yang berkenaan dengan masalah yang akan diteliti, perumusan masalah, kemudian mengaplikasikannya dengan data lapangan.

Dari hasil data lapangan baik sebelum pengujian maupun sesudah pengujian dailakukan analisa dan disimpulkan.

Lokasi penelitian dilakukan pada sumur minyak dilapangan $\mathrm{X}$ yang dikelolah oleh PT. Chevron Pacific Indonesia.

\section{HASIL DAN PEMBAHASAN}

Pemilihan sumur-sumur yang mungkin akan memberikan keuntungan, jika dilakukan pengasaman merupakan langkah pertama yang harus dilakukan untuk memperoleh keberhasilan yang maksimal dari suatu operasi pengasaman.Untuk mengaplikasikan teori penentuan pengasaman ini diambil data sumur dari suatu lapangan minyak.

\begin{tabular}{|c|c|c|c|}
\hline Parameter & Notasi & unit & Besaran \\
\hline Tekanan reservoir & $\mathrm{Pr}$ & psi & 450 \\
\hline ati-jaxis sumus & $R w$ & $\mathrm{ft}$ & 0,5 \\
\hline Jari-jaxi pengurasan & $\mathrm{Re}$ & $\mathrm{ft}$ & 550 \\
\hline Viscositas air & $W$ & $\mathrm{cp}$ & 0,5 \\
\hline Viscositas oil & 0 & $\mathrm{cp}$ & 3,4 \\
\hline Fak Vol Fomassi & Bo & $\mathrm{SCf} / \mathrm{stb}$ & 1,01 \\
\hline Permeablitas & $\mathrm{K}$ & $\mathrm{mD}$ & 3000 \\
\hline tebal interval & $\mathrm{H}$ & $\mathrm{ft}$ & 12 \\
\hline water cut & $W C$ & $\%$ & $91 / 92,45$ \\
\hline Temperatur & $\mathrm{T}$ & of & 198 \\
\hline Total Depth & $\mathrm{D}$ & $\mathrm{ft}$ & 2374 \\
\hline
\end{tabular}

Tabel 2 Data Lapangan Sumur X 
Mmenentukan sumur ini ada atau tidaknya scale dipergunakan metoda Stiff dan Davis

$$
Q=\frac{0.00708 \times \mathrm{kxh}(\mathrm{pr}-\mathrm{Pwf})}{\mu \times \beta o\left(\ln \left(\frac{\mathrm{re}}{\mathrm{rw}}\right)\right.}
$$

Dari hasil perhitungan SI positif berarti pada sumur tersebut ada Scale. Perhitungan skin, laju alir, PI dan flow effisiensi.

Skin (sebelum acidizing) :

$S=\frac{(0.00708 \times 3000 \times 12 \times(811.4-206.5))-\left(3.4 \times 1.01 \times 12\left(\frac{520}{0.5}\right) 2200\right)}{2200}=46.2$

Skin (sesudah acidizing) :

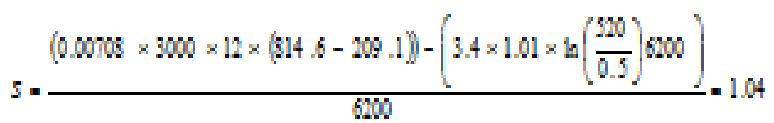

Laju alir (sebelum Acidizing) :

$q=\frac{0.00708 \times 3000 \times 12 \times(8114-206.5)}{3.4 \times 1.01 \times\left(\ln \left(\frac{520}{0.5}\right)+46.2\right)}=2200.77 B F P D$

Laju Alir (sesudah Acidizing) :

$$
q=\frac{0.00708 \times k \times h \times(p r-p w f)}{\mu_{c} \times B o \times\left(\ln \left(\frac{r e}{n w}\right)+S\right)}
$$

PI (sebelum Acidizing) :

$$
P I=\frac{Q}{\mathrm{Pr}_{\mathrm{r}}-\mathrm{P}_{w f}}=\frac{2200}{8114-206.5}=3.6 \mathrm{BFPD} / \mathrm{psi}
$$

\section{PI (sesudah Acidizing) :}

$$
P I=\frac{Q}{\operatorname{Pr}-P_{w f}}=\frac{6200 B F P D}{814.6-209.1}=10.24 B F P D / p s i
$$

Flow effisiensi (sebelum) :

$$
F E=\frac{\ln \left(\frac{r \varepsilon}{n w}\right)-0.75}{\ln \left(\frac{r \varepsilon}{n w}\right)-0.75+S}=\frac{\ln \left(\frac{520}{0.5}\right)-0.75}{\ln \left(\frac{520}{0.5}\right)-0.75+46.2}=-0.15
$$

Flow effisiensi (sesudah) :

$$
F E=\frac{\ln \left(\frac{r e}{r w}\right)-0.75}{\ln \left(\frac{r \varepsilon}{n w}\right)-0.75+S}=\frac{\ln \left(\frac{520}{0.5}\right)-0.75}{\ln \left(\frac{520}{0.5}\right)-0.75+1.04}=1.20
$$

\begin{tabular}{|c|c|c|c|c|c|c|c|c|}
\hline \multirow[t]{2}{*}{ Well } & \multicolumn{2}{|c|}{ Skin } & \multicolumn{2}{|c|}{$\begin{array}{l}\text { Laju alir } \\
\text { (Q,(BFPD) }\end{array}$} & \multicolumn{2}{|c|}{$\begin{array}{c}\mathrm{PI} \\
(\mathrm{BFPD} / \mathrm{psi})\end{array}$} & \multicolumn{2}{|c|}{$\mathrm{FE}$} \\
\hline & Sebelum & Sesudah & Sebelum & Sesudah & Sebelum & Sesudah & Sebelum & Sesudgh \\
\hline Minyak & 46.2 & 1.04 & 2200.77 & 6199 & 3.6 & 10.24 & -0.15 & 1.20 \\
\hline
\end{tabular}

Hasil perhitungan diatas dapat dilihat pada table dibawah ini menunjukkan kenaikan laju alir fluida,

Tabel 2 Hasil penentuan harga skin

\section{KESIMPULAN}

1. Jenis asam yang compatible digunakan yaitu Mud Acid (HCL + HF), karena data lapangan didapat mineral quartz (grain)

2. Setelah dilakukan Pengasaman dapat dilihat adanya perubahan nilai Skin, hal ini berarti adanya perbaikan sumur dan kerusakan Formasi dapat di atasi.

3. Jenis asam ini dapat juga digunakan untuk sumur - sumur yang lain dengan komposisi mineralnya sama. 
4. Dilihat dari hasil peningkatan laju produksi minyak setelah pengasaman dapat dikatagorikan pengasaman ini berhasil.

IV. DAFTAR SIMBOL

Q = Laju Produksi fluida (BFPD)

PI = Produktivitas Indeks

(BFPD/PSI)

$\mathrm{FE} \quad=$ Flow Efficiency

re $=$ Jari jari Pengurasan.(acre)

rw $\quad=$ Jari jari sumur(ft)

$\mathrm{k}=$ = Permeabilitas (md)

$\mathrm{P} \quad=$ Tekanan ( Psi)

$\mathrm{S} \quad=$ Skin

$\mathrm{h}=$ Ketebalan formasi $(\mathrm{ft})$
Pwf = Tekanan alir dasar sumur (Psi)

\section{DAFTAR PUSTAKA}

1. Best Practices series,Scale Preventation, Halliburton.

a. Chemical Stimulation Manual

b. Halliburton, .

2. Susanto Eddy, Perencanaan terbentuknya Scale dengan cara menginjeksikan scale inhibitor kedalam sumur produksi dilapangan minyak.

3. Suryanto, Bahan Kimia Untuk Teknik Perminyakan, Penerbit Kondur Petrolium SA, 5 Oktober 1999 